\title{
CONFLICT OF LAWS ASPECTS OF INTERNATIONAL BONDS TRANSACTIONS
}

\section{КОЛІЗІЙНІ АСПЕКТИ ПРАВОЧИНІВ 3 МІЖНАРОДНИМИ ОБЛІГАЦІЯМИ}

\section{КОЛЛИЗИОННЫЕ АСПЕКТЫ СДЕЛОК С МЕЖДУНАРОДНЫМИ ОБЛИГАЦИЯМИ}

\section{Vygovskyy O.I.}

Doctor of Jurisprudence, Associate Professor of Law, Professor of Department of Private International Law, Institute of International Relations at Taras Shevchenko National University of Kyiv. E-mail: aleks5@ukr.net

\section{Виговський О. I.}

Доктор юридичних наук, доцент, професор кафедри міжнародного приватного права Інституту міжнародних відносин Київського національного університету імені Тараса Шевченка. Електронна пошта: aleks5@ukr.net

\section{Выговский А. И.}

Доктор юридических наук, доцент, профессор кафедры международного частного права Института международных отношений Киевского национального университета имени Тараса Шевченко. Электронная почта: aleks5@ukr.net

\begin{abstract}
This article examines conflict of laws issues related to issue and circulation of international bonds at international capital markets. It covers characteristic features of international bonds as financial instruments used for raising capital from sophisticated investors which determine, in particular, peculiarities of solving conflict of laws issues. These issues include determination of the law applicable to the formal and essential validity of an international bond, the rights and liabilities as between the issuer and the holder of the international bonds, legal status of a holder of such bonds, the questions of whether a holder obtains full title from a transferor and how title is to be transferred, and whether the transferee obtains title subject to or free from any defects in title of the transferor. The author specifies possible solutions of this conflict of laws puzzle that may include different competing legal systems. He argues that in common law and some other jurisdictions the fundamental lex voluntatis principle may also be applicable to international bonds due to their contractual nature resulting in possibility to choose the governing law for the bonds. The conventional approach as to the proprietary issues of the bonds refers to the lex situs of these securities as the governing law for these issues. The conclusions formulated at the end of the article present the author's personal attitude towards legal solution of the problems related to determination of the applicable law for international bonds.
\end{abstract}

Key words: international bonds, conflict of laws, issuer, governing law, lex voluntatis.

Анотація. У иій статті досліджуються колізійні питання, щуо стосуються випуску та обігу міжнародних облігачій на міжнародних ринках капіталу. У ній висвітлюються характерні ознаки міжнародних облігащій як фінансових інструментів, щэо використовуються для залучення капіталу від інституційних інвесторів, які визначають, зокрема, особливості вирішення колізійних питань. Ці питання включають визначення права, щчо застосовується до формальної та матеріальної дійсності міжнародних облігацій, прав та обов'язків, щзо визначають відносини між емітентом та власником міжнародних облігацій, правового статусу держателя таких облігацій, питань переходу права власності від продавия до набувача, способу передачі права власності та наявності 
будь-яких дефектів титулу власності, щ⿻о переходять при такій передачі. Автор визначає можливі иляхи вирішення иієї колізійної проблеми, за якої конкуруючими можуть бути декілька правових систем. Він наголошує на тому, щьо у краӥнах загального права та деяких інших юрисдикціях основоположний принцип автономії волі сторін може також застосовуватися по відношенню до міжнародних облігащій в силу їх договірної природи, щэо визначає можливість обрання права, застосовного до облігащій. Традииійний підхід до вирішення колізійного питання відносно речово-правових аспектів обігу облігацій вказує на застосування колізійної прив'язки lex situs як права, ще застосовуватиметься до таких питань. Висновки, сформульовані наприкінці статті, представляють авторську позицію стосовно розв'язання проблем визначення застосовного права відносно міжнародних облігаиій.

Ключові слова: міжнародні облігачії, колізійне право, емітент, застосовне право, принции автономії волі.

Аннотация. В данной статье исследуются коллизионные вопросы, касаюшиеся выпуска и обращения международных облигаций на международных рынках капитала. В ней выделяются характерные признаки международных облигачий как финансовых инструментов, использующихся для привлечения капитала от институциональных инвесторов, которые определяют, в частности, особенности разрешения коллизионных вопросов. Эти вопросы включают определение права, применимого $\kappa$ формальной $u$ материальной действительности международньлх облигаций, правам и обязанностям, определяющим отношения эмитента и владельца международных облигаций, правовому статусу держателя таких облигаций, вопросам перехода права собственности от продавиа к покупателю, способу передачи права собственности и наличию каких-либо дефектов титула собственности, которые переходят при такой передаче. Автор определяет возможные пути разрешения этой коллизионной проблемы, в условиях которой конкурируюшими могут быть несколько правовых систем. Он подчеркивает, что в странах общего права и некоторых других юрисдикциях основополагающий принщип автономии воли сторон может также применяться по отношению кмеждународным облигациям в силу их договорной природы, что определяет возможность выбора права, применимого $\kappa$ облигациям. Традиционный подход к разрешению коллизионного вопроса относительно вещно-правовых аспектов обращения облигаций указывает на применение коллизионной привязки lex situs как права, применимого к таким вопросам. Bыводы, сформулированные в конце статьи, представляют авторскую позищию касательно разрешения проблем определения применимого права в отношении международных облигаџий.

Ключевые слова: международные облигаџии, коллизионное право, эмитент, применимое право, принции автономии воли.

General statement of problem. Bonds are usually defined as securities issued by the company or sovereign debtor and evidencing the debt, i.e. obligation of the issuer to pay the par value of the bond (the principal amount of debt) and interest stipulated by the terms of issue to the bondholders upon expiry of the specified term or at an earlier redemption date. In essence, bonds are ipso facto the loans made by investors to the issuer which are evidenced by debt securities. The purchaser of the bonds becomes a creditor of the issuer of the bonds, since the investor will have a right to get repayment of the principal amount of the bond which it has paid to purchase the bond. The investor obtains a return on its investment in the form of interest on the bond either at a fixed rate or at a floating rate, or by way of a discount on the face value of the bond. Each bondholder is deemed to have a separate contract with the issuer.

Bond as a financial instrument possesses the following legal characteristics: 
- It is a debt instrument which seeks to enable the holder to possess direct legal rights as against the issuer;

- It contains the promise of the issuer that the par value of the bond will be paid to the holder on a specified maturity date or, in certain circumstances, at an earlier redemption date;

- It also contains a promise that the issuer will pay interest to the holder of the bond on the principal amount until final maturity or earlier redemption, at a fixed or floating rate of interest.

International bonds (often called Eurobonds, so we shall further use both terms as synonyms) are customarily issued as bearer instruments which seek to enable the holder to possess direct legal rights as against the issuer; they are transferable by delivery (without any other formal acts) and are negotiable instruments. Negotiability means that title to and property in the instrument and all rights under it shall pass to a bona fide holder for value by physical delivery. A bona fide transferee acquires a good title free of any defects available against the claims of any transferor or holder. Such negotiability is important in relation to sales of Eurobonds in the secondary markets. Being a bearer security, a Eurobond can be more easily transferred in a cross-border dimension.

The issue of international bonds is one of the most important mechanisms for raising longterm finance in the international capital markets. It is commonly used by sovereign states, state corporations, municipal authorities, transactional corporations and banks as an alternative to borrowing from a syndicate of banks by means of a conventional international syndicated loan. Eurobonds present a method of direct investment ensuring for the issuer the accumulation of significant capital by attracting long-term foreign investment [Shutova, 2002: 39]. International bonds constitute a major financing vehicle for international finance. Within the framework of their issue a borrowing entity (the issuer) which needs to raise long-term capital issues a number of debt securities, the value of which in the aggregate equals total amount of finance required by the issuer of the bonds.

As a matter of practice, international bonds are bearer negotiable instruments where the issuer and investors belong to different jurisdictions and normally are held by institutional investors [Wood, 2007: 193-194]. They are issued by an issuer at the international capital market outside the home jurisdiction of the issuer which is not resident in the country of the place of issue of the bonds. They are purchased by investors from different jurisdictions outside the jurisdiction of the issuer. The initial 'target audience' of the international bonds are international investors from different countries across the world. International bonds are usually denominated in the currency which is foreign both for the issuer and (usually) for the country of the place of issue. International bonds are normally directed to qualified or sophisticated investors, so they can be issued without compliance with the national securities regulation for the issues made available to public. Finally, international bonds are typically sold by the syndicates of investment banks having registered offices in different jurisdictions. There are also so-called parallel issues of bonds placed by several tranches simultaneously in several states, and in each jurisdiction the relevant tranche is denominated in its national currency [Popova, 2001: 46]. The formal characteristic of the Eurobonds is the absence of a single national market of their placement and trading [Rich, 19791980: 505].

As we can see from this outline of the principal features of these financial instruments, international nature of the Eurobonds, involvement of entities from various jurisdictions within the process of their issue and placement, a variety of other foreign elements related to the issue of and transactions with international bonds inevitably gives rise to conflict of laws issues. It is in the context of such a truly international transactional framework that the question of applicable law frequently arises. The complexity of these issues is underpinned by complex legal nature of bonds as securities and multiplicity of jurisdictions involved in cross-border transactions with such securities. Transactions with Eurobonds are so 'delocalized' that determination of the applicable law concerning each particular issue is connected with significant problems [Delaume, 1972: 241]. In view of the need for integration of Ukraine into international capital markets and protection of 
the investors purchasing Eurobonds the solution of the problem of determination of the applicable law to different aspects related to these financial instruments seem very timely and topical issue.

Recent researches and publications. In international scholar community problems related to Eurobonds were highlighted, in particular, by F.G. Fischer [Fischer, 1981; Fischer, 1988], N. Horn [Horn, 1977], M. Issad [Issad, 1989], I.M. Kerr [Kerr, 1984], T. Prime [Prime, 1990], F.C. Rich [Rich, 1979-1980], R. Tennekoon [Tennekoon, 1991], S. Weber [Weber, 1999], Ph. R. Wood [Wood, 2007]. In the legal doctrine in post-Soviet states, however, these problems have been only incidentally considered, in particular, by M.V. Popova [Popova, 2001], A. Shamraev [Shamraev, 2009], E. Shutova [Shutova, 2002]. Our present research presents a modest contribution to scientific investigations in this field.

The purpose of this article is to examine conflict of laws issues pertaining to international bonds and possible ways of their solution taking into consideration complex legal nature of these debt instruments, their contractual essence and cross-border dimension of their circulation and trading.

Main research results. The issues which may involve a conflict of laws in respect of the Eurobonds embrace, inter alia, the following:

a) Which law determines the formal and essential validity of a Eurobond?

b) Which law determines the rights and liabilities as between the issuer and the holder of the Eurobond? In particular, what law determines whether terms in trust deeds and fiscal agency agreement are part of the legal regime regulating the rights and liabilities of the issuer and holder?

c) Which law determines whether a person is a holder or a bona fide holder of the Eurobond?

d) Which law determines whether a holder obtains full title from a transferor and how title is to be transferred?

e) Which law determines whether the transferee obtains title subject to or free from any defects in title of the transferor?

Possible solutions of this conflict of laws puzzle may include the following legal systems:

- lex societatis (i.e. law of the place of incorporation or law of the seat) of the issuer;

- law of the place of closing of the issue of the Eurobonds (as the lex loci contractus of the Eurobonds);

- lex monetae referring to the currency of the debt evidenced by a Eurobond;

- law of the place of performance (place of payment) under the Eurobonds (as their lex loci solutionis) etc.

There are no international conventions that would govern the conflict of laws issues of the Eurobonds. In fact, the international regulation of these instruments is effected with the use of recommendations and rules developed by international associations and other institutions. These recommendations have the status of transnational law [Horn, 1977: 753]. At the doctrinal level there is no uniform approach towards determination of the applicable laws in relation to Eurobonds. It is suggested that various aspects related to Eurobonds should be governed by different legal systems. For instance, it is suggested that terms and conditions of the issue of Eurobonds should be governed by the national laws of the state of location of the issuer, while terms and conditions of their circulation should be determined by the rules of a particular stock market [Tosunian, 2002: 724].

In the common law and some other jurisdictions bonds are viewed as the securities having contractual nature and belonging to the negotiable instruments. A bond is seen as a kind of loan agreement in which the issuer plays the role of the borrower, and the bondholders are the creditors of the issuer for the offering price of the bonds. Since a bond is a contract sui generis binding and enforceable as between the issuer and the investor, then the fundamental lex voluntatis principle may well be applicable resulting in possibility to choose the governing law for the bonds. In fact, at least in the English-based jurisdictions nothing prevents the parties from choosing the proper law (usually expressed on the face of the instrument or in the choice of law clause in the terms of issue contained in the prospectus) to govern at least the contractual elements of a bond instrument. This 
would mean that at least issues (a) and (b) listed above may be governed by reference to a single chosen system of law.

An express choice of the English law (which choice is very often the case for the Eurobonds issue) is normally recognized and upheld by the English courts as governing at least the contractual aspects of the bonds, even though England is not the lex loci contractus of the bonds (for example, in the case of an issue of Eurobonds nominated in Euro and effected in Paris subject to an English proper law clause).

This approach is also supported in the legal doctrine; it is suggested that in case of the bonds the law governing loan will be applicable, in other words, the party autonomy principle shall apply [Issad, 1989: 169]. It was also submitted that since terms and conditions of the bonds constitute a contract between the issuer and the investor (bondholder), then the principles of determination of lex causae of a contract shall apply to a bond [Weber, 1999: 30]. It was concluded that this approach fully corresponds with the party autonomy doctrine applicable to commercial contracts [Tennekoon, 1991: 168-169]. Some scholars raise an issue of the need for elaboration of the doctrine of a formal contract attested by a security [Murzin, 1998: 43]. The elimination of the issues related to negotiable instruments from the scope of application of international instruments containing conflict of laws rules applicable to contracts, such as the Rome Convention 1980 on the Law Applicable to Contractual Obligations [1] and Regulation (EC) No 593/2008 of the European Parliament and of the Council of 17 June 2008 on the law applicable to contractual obligations (Rome I) [2], does not mean that conflict of laws principles applicable to contracts cannot be employed for international bonds. It was suggested that the Rome Convention 1980 excludes from its scope only contracts related to issue of a negotiable instrument, and not the underlying contracts or contracts on their transfer [Kaye, 1993: 116].

Such a choice would enable predictability and certainty in respect of legal rights and liabilities of the issuer and the bondholder arising out of these instruments at the time of their issue. This is extremely important in practice, since many concepts, notions, terminology and legal techniques used in the Eurobonds market (including no-action clause, negative pledge clause, pari passu clause, cross-default clause, bondholders' trust etc.) are predominantly of the English law origin. Therefore, incidental application by the competent court of the legal system which ignores such concepts and notions and their further re-characterization for the purposes to adapt these notions to the reality of the continental legal system (which is often the case in respect of trust, for example) may lead to disastrous effect for all the parties to the Eurobonds transactions. Consequently, traditional choice of the English law reflects not only the intention of the issuer to ensure applicability of this system of law to the Eurobonds, but rather its wish to insulate legal relations arising in respect of the Eurobonds from application of any 'unacceptable' and 'extraneous' system of law which may inevitably cause re-characterization risk. However, it should be borne in mind that choice of the English law may not be seen as a cure-all solution, since the competent court of a foreign jurisdiction may tend to apply indigenous lex fori in order to protect the interests of its nationals being the investors in the Eurobonds or in view of the public policy considerations, and this disregard of the chosen law represents a major legal risk for the issuer.

This approach leaves open the question as to which law governs the proprietary aspects of the Eurobonds, i.e. items (c) to (e) from the list above, which includes the essence of negotiability of the bond instruments. The conventional approach as to the proprietary issues of the securities refers to the lex situs of the securities as the governing law for these issues. Since the Eurobonds belong to negotiable instruments, then the place of delivery of these instruments should determine the choice of law for the proprietary issues. However, it is submitted that this conflict of laws principle is very difficult to apply to such securities in reality.

Nowadays the Eurobonds are usually issued in a non-documentary form; even if the definitive Eurobonds were issued, they are warehoused with a depository for the clearance system. Within the multi-tiered securities holding system the clearance system holds the bonds for the account of their respective securities account holders. Where a transfer occurs, it always takes place between one securities account holder of the clearance system and another account holder. Consequently, all 
transfers are effected within the electronic book-entry system without any movement of the physical definitive Eurobonds. Thus, 'delivery' of a Eurobond under such circumstances is so 'delocalized' and the place of delivery is so difficult to ascertain that lex situs rule brings almost no success in solving this conflict of laws puzzle. The place of delivery may be determined as the country where the bonds are physically warehoused or where the electronic book-entry system is located, and both such locations may have no relation to the actual transaction.

In view of these circumstances, in order to achieve a greater level of predictability and certainty a new approach is needed. Since virtually all Eurobonds contain a choice of law clause which expressly subjects the bond to a specific system of law for the purposes of governing all rights and obligations arising out of the bond, then this express choice of law clause should also govern the negotiability of the bond regardless of the actual place of transfer which may be purely accidental and thus irrelevant for conflict of laws purposes. This express choice of law should govern not only the relationship between the transferor and transferee and successive transferees, but also the rights of a transferee as against the issuer of the Eurobond. Such an approach is not inconsistent with the case law. For instance, in the decisions in Alcock v. Smith [3] and Embiricos v. Anglo-Austrian Bank [4] related to the bond instruments containing no express choice of law clauses the Court of Appeal applied the law of the place of delivery of the documents for determining the negotiability of the securities.

Such an approach is also extremely desirable from a practical point of view because it creates certainty in a complex financial transaction which involves innumerable parties from a large number of countries with different systems of law. In particular, it would enable the terms and conditions of the bond instrument to be tested for validity by a system of law chosen to govern the matter at the time of the issue of the instrument and by reference to which the terms and conditions may be drafted. Further, such an approach is consistent with the doctrine of party autonomy which sometimes tends to by extended to cover the proprietary issues of a transaction. Finally, in many cases the bank which acts as the depository physically holds the Eurobonds (the global bond) with the chosen English law in London, so the lex situs of delivery will coincide with the express choice of law leading to the same result in terms of conflict of laws regulation of proprietary issues of the Eurobonds transactions.

Conclusion. Since a bond is a contract sui generis binding and enforceable as between the issuer and the investor, then the fundamental lex voluntatis principle may well be applicable resulting in possibility to choose the governing law for the bonds. The law chosen by the issuer will govern the contractual elements of a bond instrument, including the rights and obligations of the issuer and bondholders. Traditional choice of the English law is designed to insulate legal relations arising in respect of the Eurobonds from application of any 'extraneous' system of law which may inevitably cause re-characterization risk. However, in some jurisdictions this choice may be disregarded in favor of lex fori of the court considering the case of protection of national investors. The conventional approach as to the proprietary issues of the securities refers to the lex situs of the securities as the governing law for these issues. Since the Eurobonds belong to negotiable instruments, then the place of delivery of these instruments should determine the choice of law for the proprietary issues. In case of the international bonds existing in non-documentary form an express choice of law clause should also govern the negotiability of the bond regardless of the actual place of transfer which may be purely accidental and thus irrelevant for conflict of laws purposes.

\section{References}

1. Council Regulation (EC) No.593/2008 of the European Parliament and of the Council of 17 June 2008 on the Law Applicable to Contractual Obligations (Rome I) // Official Journal of the European Union. L177/6. 04.07.2008.

2. Rome Convention on the Law Applicable to Contractual Obligations, opened for signature in Rome on 19 June 1980 (80/934/EEC) // Official Journal of the European Union. L266. 09.10.1980. 
3. $\quad$ Alcock v. Smith [1892] 1 Ch. 238.

4. $\quad$ Embiricos v. Anglo-Austrian Bank [1905] 1 K.B. 677.

5. Delaume G. R. (1972) 'Choice of Law and Forum Clauses in Euro-Bonds', Columbia Journal of Transnational Law, 11: 240-266.

6. Fischer F.G. (1988) Eurobonds. London: Euromoney.

7. Fischer F.G. (1981) International Bonds. London: Euromoney Publications.

8. Horn N. (1977) 'A Uniform Approach to Eurobond Agreements', Law and Policy in International Business', 9: 753-756.

9. Kaye P. (1993) The New Private International Law of Contract of the European Community: Implementation of the EEC's Contractual Obligations Convention in England and Wales under the Contracts (Applicable Law) Act 1990. Aldershot: Dartmouth.

10. Kerr I. M. (1984) A History of the Eurobond Market: the first 21 years. London: Euromoney.

11. Prime T. (1990) International Bonds and Certificates of Deposit. Sevenoaks: Butterwoths.

12. Rich F. C. (1979-1980) 'Eurobond Practice: Sources of Law and the Threat of Unilateral National Regulation', Virginia Journal of International Law, 20:505-545.

13. Tennekoon R. C. (1991) The Law and Regulation of International Finance. London: Butterworths.

14. Weber S. (1999) The Law Applicable to Bonds in 'The Law of Cross-Border Securities Transactions'. London: Sweet \& Maxwell.

15. Wood P. R. (2007) International Loans, Bonds, Guarantees, Legal Opinions. London: Sweet \& Maxwell.

16. Иссад М. (1989) Международное частное право [Private International Law]. Москва: Прогресс.

17. Мурзин Д. В. (1998) Ценные бумаги - бестелесные вещи. Правовые проблемы современной теории ценных бумаг [Securities - Incorporeal Things. Legal Problems of Contemporary Theory of Securities]. Москва: Статут.

18. Попова M. B. (2001) Правовые проблемы выпуска облигаций российскими коммерческими банками [Legal Problems of Issue of Bonds By Russian Commercial Banks] Банковское право, 4: 37-56.

19. Тосунян Г.А. (2002) Банковское право Российской Федерации. Особенная часть. Том 2. [Banking Law of the Russian Federation. Specific Part. Volume 2]. Москва: Юристь.

20. Шамраев А.В. (2009) Правовое регулирование международных банковских сделок и сделок на международных финансовых рынках [Legal Regulation of International Banking Transactions and Transactions at International Financial Markets]. Москва: Кнорус.

21. Шутова E. (2002) Еврооблигация и применимое право [Eurobonds and Governing Law] Коллегия, 10-11: 39-40. 